\title{
Effect of Feeding Graded Levels of Fermented Sweet Orange (Citrus Sinensis) Fruit Peel Meal on the Growth and Nutrient Digestibility of Broiler Chicken
}

\author{
O.I.A. Oluremi ${ }^{* 1}$, A.A. Ahile ${ }^{2}$, T.F. Jande ${ }^{2}$ \\ ${ }^{1}$ Department of Animal Nutrition, Federal University of Agriculture, Makurdi, Benue State. Nigeria. \\ ${ }^{2}$ Department of Animal Production, Federal University of Agriculture, Makurdi, Benue State. Nigeria.
}

\begin{abstract}
A sixty-three day feeding trial was conducted with one hundred and eighty (180) day-old Anak 2000 broiler chicks with an average weight of $54.26 \mathrm{~g}$. They were randomly assigned in groups of 30 each to 6 dietary groups $T_{0}, T_{10}, T_{20}, T_{30}, T_{40}$, and $T_{50}$ which had 24-hour fermented sweet orange fruit (Citrus sinensis) peel as a replacement for maize at $0,10,20,30,40$, and 50\% respectively, to determine their growth performance. Each treatment group had 3 replicates with equal no of chicks in a completely randomized design. The birds were provided with water and feed ad libitum. Body weight and feed intake were taken, water intake measured, feed conversion ratio, body weight gain and water: feed ratio calculated. A five (5) day Digestibility trial was done in the night week with three (3) chickens per treatment to determine nutrient digestibility. Replacement of maize with sweet orange peel significantly retarded $(p<0.05)$ final live body weight gain, and the feed conversion ratio of broiler chickens and elevated the water : feed ratio. Nutrient digestibility was not significantly affected $(p>0.05)$. The study showed that utilisation of 24-hour fermented sweet orange peel as a dietary replacement for maize at levels of 10\%-50\% did not support the growth of broiler chicken. It is recommended that sweet orange peel be fermented for longer duration beyond 24 hours to further evaluate its potential feed value in broiler chicken diet.
\end{abstract}

Keywords- Fermentation, orange peel, Growth, chicken.

\section{INTRODUCTION}

Animal protein intake in Nigeria from meat, egg and milk sources as in some developing countries is low with attendant effects of malnutrition and lowered human productivity. This is partly due to the high costs of these finished products as a result of high feeding costs and disease problems with its toll on animal population in spite of growing human population. In addition, climate change is also exerting negative environmental effect on the animals. Monogastric animals especially birds compete with man for conventional feedstuffs especially cereal grain because of increase in human population and food industries particularly, and lowered cereal and legume grain farm outputs occasioned by climate change. This has thus increased the demand for protein of animal origin (Oluwafemi, 2009). Large scale commercial poultry production is one quick and effective way of correcting the problem of animal protein intake deficiency, and broiler chickens are usually the most universal and important as producers of table meat. Agroallied by-products have in the past 40 years become important feed components in monogastric diets in Nigeria, to reduce the demand pressure on convectional feedstuffs. Whereas, oil seed cakes are used often as protein component in monogastric diets, agro by-products from fruits and tubers are used as replacement for maize or grain, the energy component. The use of some of these by-products are associated with problems like presence of anti-nutritional factors harmful to the animal health and high fibre content which reduces the feed value of these agricultural by-products, thereby making their processing before use in animal feed critical. Cassava products contain cyanogenic glucoside which can be reduced by cooking, frying, drying and fermentation (Udedibe et al., 2004). Sweet orange peels have been reported to contain limonene, saponin, tannin, flavonoid, phytate, oxalate (Oluremi et al., 2007b) which could be reduced by fermentation. Processing is done to reduce moisture content to prevent spoilage and increase shelf life, remove harmful compounds, improve nutrient availability and digestibility with overall effect on the enhancement of the nutritional value of the by-product. The usefulness of a nutrient to an animal depends on its digestibility, and digestibility is affected by anti-nutritional factors (Longe, 2006; Panda, 2006). Thus, digestibility of any given feed by broiler chicken is a prerequisite for good performance. 
The objective of this study was to determine the effect of replacing maize with graded levels of fermented sweet orange fruit peel on the performance of broiler chickens.

\section{MATERIALS AND METHODS}

\section{Experimental site}

The feeding trial was carried out at the Poultry unit in the Teaching and Research Farm, Federal University of Agriculture Makurdi, Benue State, Nigeria.

\section{Processing of Sweet orange fruit peel and Preparation of Experimental Diets}

Fresh sweet orange peels were gathered from orange fruits sellers within the Makurdi metropolis. They were packed into empty feed sacks, tied at open end, and allowed 24hours to ferment. Thereafter, they were spread on concrete platform and sun-dried to less than $10 \%$ moisture within 48hours. The sun-dried peels were ground, added to other feedstuffs and manually mixed to compound the experimental diets. Six diets coded $\mathrm{T}_{0}, \mathrm{~T}_{10}$, $\mathrm{T}_{20}, \mathrm{~T}_{30}, \mathrm{~T}_{40}$ and $\mathrm{T}_{50}$ for each of starter broiler (Table 1) and finisher broiler (Table 2) were formulated, with sweet orange peel replacing dietary maize at $0,10,20,30,40$ and $50 \%$ respectively.

\section{Experimental animals, Design and Management}

One hundred and eighty (180) day-old Anak 2000 broiler chicks were purchased from TUNS Farm in Nigeria and used for the feeding trial. They were randomly allocated using the Table of random numbers (Little and Hills, 1977) to six dietary treatments balancing for live weight. Each treatment had three replicates with 10 chicks each. The experiment was completely randomized design.

The experimental birds were brooded with kerosene lantern and charcoal as sources of illumination and heat respectively. They were raised in deep litter system, fed and served drinking water ad libitum for sixty-three days. Newcastle vaccine was given at day-old and week 5, and infectious bursal disease (gumboro) vaccine at week 4 . Coccidiostat was given at preventive dose at alternate weeks because coccidiosis was endemic in the research environment. Neomycin chick formula (antibiotics) was given to the birds on arrival, in addition with Vitalyte (antistress) which was periodically given pre- and postweekly weighing of the experimental birds and administration of vaccine. Drinkers were washed, litter materials in the feeder were removed daily and litter on the floor was maintained dry to secure the health of the birds.

\section{Data collected and Statistical analysis}

Feed intake was determined weekly and daily feed intake computed. Daily water intake was obtained from known quantities of water served 24 hourly less the unconsumed water, and the evaporative water loss using the procedure of Shoremi et al. (1998). Body weight of each replicate was taken weekly and body weight gain calculated by difference (current weight less former weight). Feed conversion ratio was calculated as feed intake: body weight gain ratio and water: feed ratio computed.

In the last week of the feeding trial, one chicken per replicate with average weight similar to that of the treatment group was transferred into the metabolic cage. After a 2-day adjustment period, weighed treatment diets were served daily for 5 consecutive days, fresh faecal outputs collected daily, weighed, oven dried, and reweighed. Dried faecal outputs per replicate were pooled, milled and analysed along with the experimental diets to determine their proximate constituents (AOAC, 1995).

The data obtained were analysed using the analysis of variance (Steel and Torrie, 1980) and where significant difference was observed among treatment means, least significant difference was used for mean separation.

\section{RESULTS AND DISCUSSION}

The effect of replacement of maize with fermented sweet orange fruit peel in the diet of broiler chicken on growth performance is in Table 3. The live weight, feed intake, body weight gain, feed conversion ratio and water: feed ratio obtained were significantly different $(\mathrm{p}<0.005)$ among the treatments whereas, water intake was not ( $>0.05$ ). The final live weight, feed intake, body weight gain tended to decrease whereas, feed conversion ratio and water: feed ratio became poorer as the percent maize replacement with sweet orange peel increased from $0 \%$ to $50 \%$. The utilisation of sun-dried 24 hours fermented sweet orange fruit peel as a replacement for maize depressed the growth of broiler chickens and this negative effect became more severe at higher levels. This showed that sweet orange fruit peel as processed in this study still had a low feed value. It has been reported that sweet orange peel has higher crude fibre content than maize (Oluremi et al. 2007a) and anti-nutritional factors (Oluremi et al. 2007b). The negative effect of alternative feed resource includes high fibre content which affects nutrient bio-availability, and anti-nutritional factor which are deleterious to animal health and growth (Dafwang, 2006). Dietary fibre stimulates water consumption and this probably caused increased water: feed ratio obtained. The effect of the experimental diets on nutrient digestibility of broiler chickens is in Table 4. The digestibility of crude protein, crude fibre, ether extract and nitrogen free extract was not significantly affected $(p>0.05)$ among the treatment means. It was also observed that the digestibility value for each nutrient was average ranging between $60 \%$ and $70 \%$. The only exception being the coefficient of digestibility of crude fibre where for chickens in $\mathrm{T}_{30}$ a value of $57 \%$ was 
obtained. The broiler chickens in the control group $\left(\mathrm{T}_{0}\right)$ did not show any superiority in nutrient digestibility compared to the chickens in the sweet orange peel based dietary treatments. The nutrient digestibility of broiler chickens may not have been a major determinant of the pattern recorded for the growth rate as given by the body weight gain which significantly declined $(p<0.05)$ as the percent replacement level of maize by sweet orange peel increased in the diet. It is therefore apparent that some of the anti-nutritional factors present in the peel as reported by Oluremi et al. (2007b) may have retarded the growth rate of the broiler chickens.

The study has revealed that the utilisation of sweet orange peel fermented for 24 hours as a replacement for maize at $10,20,30,40$ and $50 \%$ did not support the growth of broiler chickens. It is recommended that sweet orange fruit peels fermented for longer duration beyond 24 hours be evaluated for their effect on the growth response of broiler chickens.

Table.1: Composition of Broiler starter diets containing 24-hour fermented Sweet orange peel

\begin{tabular}{|c|c|c|c|c|c|c|}
\hline \multirow[t]{2}{*}{ Ingredients } & \multicolumn{5}{|c|}{ Experimental Diets } & \multirow[b]{2}{*}{$\mathrm{T}_{50}$} \\
\hline & $\mathrm{T}_{0}$ & $\mathrm{~T}_{10}$ & $\mathrm{~T}_{20}$ & $\mathrm{~T}_{30}$ & $\mathrm{~T}_{40}$ & \\
\hline Maize & 49.00 & 44.10 & 39.20 & 34.30 & 29.40 & 24.50 \\
\hline Sweet orange peel meal & 0 & 4.90 & 9.80 & 14.70 & 19.60 & 24.50 \\
\hline Soybean meal & 42.50 & 42.50 & 42.50 & 42.50 & 42.50 & 42.50 \\
\hline Brewers dried grain & 3.00 & 3.00 & 3.00 & 3.00 & 3.00 & 3.00 \\
\hline Blood meal & 1.50 & 1.50 & 1.50 & 1.50 & 1.50 & 1.50 \\
\hline Bone meal & 3.00 & 3.00 & 3.00 & 3.00 & 3.00 & 3.00 \\
\hline Common salt & 0.25 & 0.25 & 0.25 & 0.25 & 0.25 & 0.25 \\
\hline Methionine & 0.28 & 0.28 & 0.28 & 0.28 & 0.28 & 0.28 \\
\hline Lysine & 0.22 & 0.22 & 0.22 & 0.22 & 0.22 & 0.22 \\
\hline Vitamin/mineral premix & 0.25 & 0.25 & 0.25 & 0.25 & 0.25 & 0.25 \\
\hline Total & 100.00 & 100.00 & 100.00 & 100.00 & 100.00 & 100.00 \\
\hline \multicolumn{7}{|l|}{ Calculated nutrients } \\
\hline Crude protein $(\%)$ & 25.06 & 25.03 & 25.00 & 24.97 & 24.94 & 24.91 \\
\hline Crude fibre $(\%)$ & 4.46 & 5.01 & 5.56 & 6.11 & 6.66 & 7.21 \\
\hline Ether extract $(\%)$ & 3.85 & 3.77 & 3.70 & 3.63 & 3.55 & 3.48 \\
\hline Calcium (\%) & 1.10 & 1.10 & 1.10 & 1.10 & 1.10 & 1.10 \\
\hline Phosphorus (\%) & 0.88 & 0.86 & 0.85 & 0.83 & 0.82 & 0.81 \\
\hline Methionine (\%) & 0.82 & 0.81 & 0.80 & 0.79 & 0.78 & 0.77 \\
\hline Lysine $(\%)$ & 1.63 & 1.62 & 1.61 & 1.59 & 1.58 & 1.57 \\
\hline Energy (kcalME/kg) & 2820.06 & 2800.25 & 2780.45 & 2760.64 & 2740.84 & 2721.04 \\
\hline
\end{tabular}

Table.2: Composition of Broiler finisher diets containing 24-hour fermented Sweet orange peel

\begin{tabular}{lcccccc}
\hline Ingredients & \multicolumn{5}{c}{ Experimental Diets } \\
\cline { 2 - 7 } & $\mathrm{T}_{0}$ & $\mathrm{~T}_{10}$ & $\mathrm{~T}_{20}$ & $\mathrm{~T}_{30}$ & $\mathrm{~T}_{40}$ & $\mathrm{~T}_{50}$ \\
\hline Maize & 51.58 & 46.42 & 41.26 & 36.11 & 30.95 & 25.79 \\
Sweet orange peel meal & 0 & 5.16 & 10.32 & 15.47 & 20.63 & 25.79 \\
Soybean meal & 26.57 & 26.57 & 26.57 & 26.57 & 26.57 & 26.57 \\
Maize offal & 9.00 & 9.00 & 10.00 & 11.00 & 12.00 & 12.00 \\
Brewers dried grain & 6.00 & 6.00 & 6.00 & 6.00 & 6.00 & 6.00 \\
Blood meal & 3.00 & 3.00 & 3.00 & 3.00 & 3.00 & 3.00 \\
Bone ash & 3.00 & 3.00 & 3.00 & 3.00 & 3.00 & 3.00 \\
Common salt & 0.25 & 0.25 & 0.25 & 0.25 & 0.25 & 0.25 \\
Methionine & 0.25 & 0.25 & 0.25 & 0.25 & 0.25 & 0.25 \\
Lysine & 0.10 & 0.10 & 0.10 & 0.10 & 0.10 & 0.10 \\
Vitamin/mineral premix & 0.25 & 0.25 & 0.25 & 0.25 & 0.25 & 0.25 \\
\hline Total & 100.00 & 100.00 & 100.00 & 100.00 & 100.00 & 100.00 \\
\hline Calculated nutrients & & & & & 21.17 & 21.14
\end{tabular}




\begin{tabular}{lrrrrrr}
\hline Crude fibre (\%) & 4.95 & 5.52 & 6.10 & 6.68 & 7.26 & 7.84 \\
Ether extract (\%) & 3.81 & 3.73 & 3.66 & 3.58 & 3.50 & 3.42 \\
Calcium (\%) & 1.09 & 1.09 & 1.08 & 1.08 & 1.08 & 1.08 \\
Phosphorus (\%) & 0.83 & 0.81 & 0.78 & 0.78 & 0.77 & 0.75 \\
Methionine (\%) & 0.69 & 0.68 & 0.66 & 0.66 & 0.65 & 0.64 \\
Lysine (\%) & 1.21 & 1.19 & 1.18 & 1.17 & 1.15 & 1.14 \\
Energy (kcalME/kg) & 2857.97 & 2837.12 & 2816.26 & 2795.45 & 2774.49 & 2753.74 \\
\hline
\end{tabular}

Table.3: The effect of 24-hour fermented Sweet orange peel meal on Performance response of Broiler chicken

\begin{tabular}{lll}
\hline Performance indices & Experimental Diets & SEM
\end{tabular}

\begin{tabular}{|c|c|c|c|c|c|c|c|}
\hline \multirow{2}{*}{ 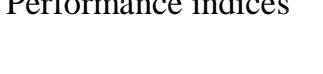 } & & \\
\hline & $\mathrm{T}_{0}$ & $\mathrm{~T}_{10}$ & $\mathrm{~T}_{20}$ & $\mathrm{~T}_{30}$ & $\mathrm{~T}_{40}$ & $\mathrm{~T}_{50}$ & \\
\hline Initial live weight (g) & 54.95 & 54.62 & 54.67 & 54.50 & 52.07 & 54.67 & \\
\hline Final live weight $(\mathrm{kg})$ & $2.01^{\mathrm{a}}$ & $1.88^{\mathrm{b}}$ & $1.73^{\mathrm{c}}$ & $1.61^{\mathrm{d}}$ & $1.50^{\mathrm{e}}$ & $1.33^{\mathrm{f}}$ & 0.03 \\
\hline $\begin{array}{l}\text { Body weight gain } \\
\text { (g/day) }\end{array}$ & $41.73^{\mathrm{a}}$ & $38.11^{\mathrm{b}}$ & $33.81^{\mathrm{c}}$ & $30.43^{\mathrm{d}}$ & $27.98^{\mathrm{e}}$ & $22.38^{\mathrm{f}}$ & 0.54 \\
\hline Feed intake ( $g /$ day) & $114.45^{\mathrm{a}}$ & $105.73^{\mathrm{b}}$ & $100.98^{\mathrm{bc}}$ & $97.95^{\mathrm{cd}}$ & $100.63^{\mathrm{bc}}$ & $94.34^{\mathrm{d}}$ & 1.91 \\
\hline Feed conversion ratio & $2.74^{\mathrm{a}}$ & $2.77^{\mathrm{a}}$ & $2.99^{\mathrm{ab}}$ & $3.22^{\mathrm{b}}$ & $3.59^{\mathrm{c}}$ & $4.23^{\mathrm{d}}$ & 0.10 \\
\hline Water intake (ml/day) & 205.37 & 212.99 & 216.42 & 225.61 & 217.75 & 213.22 & $10.12^{\mathrm{ns}}$ \\
\hline Water:Feed ratio & $1.79^{\mathrm{a}}$ & $2.01^{\mathrm{ab}}$ & $2.13^{\mathrm{b}}$ & $2.30^{\mathrm{b}}$ & $2.16^{\mathrm{b}}$ & $2.25^{\mathrm{b}}$ & 0.10 \\
\hline
\end{tabular}

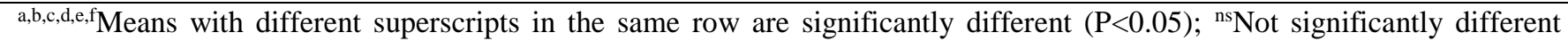
$(\mathrm{P}>0.05)$; SEM=Standard error of mean; $\mathrm{T}_{0}=0 \%$ maize replacement with sweet orange peel meal; $\mathrm{T}_{10}=10 \%$ maize replacement with sweet orange peel meal; $\mathrm{T}_{20}=20 \%$ maize replacement with sweet orange peel meal; $\mathrm{T}_{30}=30 \%$ maize replacement with sweet orange peel meal; $\mathrm{T}_{40}=40 \%$ maize replacement with sweet orange peel meal; $\mathrm{T} 50=50 \%$ maize replacement with sweet orange peel meal

Table.4: The effect of 24-hour fermented Sweet orange peel meal on nutrient digestibility by Broiler chicken

\begin{tabular}{lccccccc}
\hline \multirow{2}{*}{ Nutrient } & \multicolumn{3}{c}{ Experimental Diets } & \multicolumn{3}{c}{ SEM } \\
\cline { 2 - 6 } & $\mathrm{T}_{0}$ & $\mathrm{~T}_{10}$ & $\mathrm{~T}_{20}$ & $\mathrm{~T}_{30}$ & $\mathrm{~T}_{40}$ & $\mathrm{~T}_{50}$ \\
\hline Crude protein & 64.18 & 64.48 & 63.02 & 60.23 & 62.46 & 60.78 & $1.10^{\mathrm{ns}}$ \\
Crude fibre & 61.27 & 62.83 & 62.64 & 57.49 & 60.42 & 60.21 & $1.15^{\mathrm{ns}}$ \\
Ether extract & 65.26 & 66.88 & 66.47 & 63.78 & 62.69 & 63.74 & $0.87^{\mathrm{ns}}$ \\
Nitrogen free extract & 64.10 & 66.70 & 66.53 & 64.24 & 63.63 & 64.63 & $0.87^{\mathrm{ns}}$ \\
Metabolisable energy & $70.11^{\mathrm{ab}}$ & $69.96^{\mathrm{ab}}$ & $79.44^{\mathrm{a}}$ & $53.32^{\mathrm{b}}$ & $62.33^{\mathrm{ab}}$ & $62.33^{\mathrm{ab}}$ & 2.73 \\
\hline
\end{tabular}

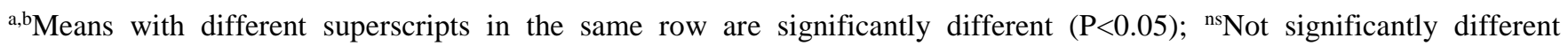
$(\mathrm{P}>0.05)$; SEM=Standard error of mean; $\mathrm{T}_{0}=0 \%$ maize replacement with sweet orange peel meal; $\mathrm{T}_{10}=10 \%$ maize replacement with sweet orange peel meal; $\mathrm{T}_{20}=20 \%$ maize replacement with sweet orange peel meal; $\mathrm{T}_{30}=30 \%$ maize replacement with sweet orange peel meal; $\mathrm{T}_{40}=40 \%$ maize replacement with sweet orange peel meal; $\mathrm{T} 50=50 \%$ maize replacement with sweet orange peel meal

\section{REFERENCES}

[1] AOAC (1995). Official Methods of Analysis. 16 $6^{\text {th }}$ Edition. Association of Official Analytical Chemists, Washington D.C. USA.

[2] Dafwang, I.I. (2006). Meat, Eggs and Milk from Farm Wastes: Explorations of Animal Nutrition Research and Extension. An Inaugural Lecture. $15^{\text {th }}$ April 2006, Ahmadu Bello University, Zaria Nigeria. $61 \mathrm{pp}$

[3] Little, T.M. and Hills, F.J. (1977). Agricultural Experimentation; Design and Analysis. John Wiley and sons, New York.
[4] Longe, O.G. (2006). Poultry: Treasure in a chest. An Inaugural Lecture, University of Ibadan on $24^{\text {th }}$ August, 2006: No 180.

[5] Oluwafemi, R.A (2009). Palm Kernel Cake Utilization in Monogastric Animal Feeding Implications for sustainable livestock development. International Journal of Veterinary Medicine 6(2): 68

[6] Oluremi, O.I., Andrew, I.A. and Ngi. J. (2007a). Evaluation of Nutritive potential of some Citrus fruits (Citrus sinensis) Varieties as Feeding stuffs in Livestock production, Pakistan Journal of Nutrition 6(6): 653-656. 
[7] Oluremi, O.I.A., Ngi. J. and Andrew, I.A. (2007b). Phyto-nutrients in Citrus fruit peel meal and Nutritional implication for Livestock feeding. Livestock Research for Rural DevelopmentVol. 19, Article http://www.cipav.org.co/lrrd/19/7olur19089.htm.

[8] Panda, A.K (2009). Phosphorous: The Essential Mineral Response of Broilers Fed with $\beta$ Mannanase in high and low energy palm kernel based diets. Proceedings $34^{\text {th }}$ Annual Conference of the Nigerian Society for Animal Production (NSAP), March 15-18 ${ }^{\text {th }}, 2009$ Pp 420-421.

[9] Shoremi, O.I.A., Ayoade, J.A. and Akinwale V.O. (1998). Maize replacement value of cassava peel soaked in water. Applied Animal Research 14: 183-187.

[10] Steel, R.G.D. and Torrie, J.H. (1980). Principles and Procedures of Statistics. A Biometrical Approach. 2nd Edition. MacGraw Books Co., USA.

[11] Udedibe, A.B.I., Anyaegbu, B.C., Onyechekwu G.C., and Egbuokporo, O.C., (2004). Effect of Feeding different levels of fermented and unfermented cassava tuber meals on the performance of broilers. Nigerian Journal Animal Production. 31: 211-217. 